\title{
DETERMINANTS OF FOREIGN DIRECT INVESTMENT IN LESOTHO: EVIDENCE FROM COINTEGRATION AND ERROR CORRECTION MODELING
}

\author{
Malefa Rose Malefane
}

Department of Economics, University of South Africa

\begin{abstract}
Over the past decade, Lesotho has recorded a substantial increase in levels of foreign direct investment (FDI) inflow, part of it prompted by trade privileges. Building on the extant literature, this study provides an empirical analysis of determinants of FDI in Lesotho. The study looks at how macroeconomic stability, regulatory frameworks, political stability and market size affect FDI. The evidence from this study shows that some of the foreign enterprises in Lesotho are there to serve a bigger South African market. Also, the country has benefited from a more export-oriented investment promotion strategy. Critical issues however remain that must be addressed if the country is to attract more FDI and retain existing investors. These issues pertain to bureaucratic red-tape, corruption and political instability.
\end{abstract}

JEL F21

\section{1 Introduction}

The evolution of the international capitalist economy and the growth of multinational corporations have been closely linked to patterns of foreign direct investment (FDI) in Africa. Widstrand and Amin (1975) state that FDI represents a central part of the international political economy. Thus, for the purpose of receiving FDI, most countries in Africa have tried to increase investor confidence through the inclusion of multilateral investment and tax agreements pertaining to FDI (UNCTAD, 1995). Since the role played by FDI in the process of a country's industrialisation is crucial, empirical studies make it possible to draw useful lessons concerning the advantages and disadvantages of different trade and investment policies. The continued sluggish FDI growth worldwide and the rising protectionism in industrial countries threaten the prospects of developing countries, many of which have begun to reduce their trade barriers from very high levels in attempts to expand exports and obtain net earnings that are needed to maintain adequate growth and to service external debt.

Lesotho, like many other countries in Africa, has opened up her economy to foreign investment. Although modest, FDI is important for Lesotho. As noted in the report by UNCTAD (2003), Lesotho's economy depends for growth, employment and export revenues on a manufacturing sector that is almost entirely driven by export-oriented FDI in the apparel industry. However, much of the FDI in manufacturing has been driven by Lesotho being a signatory and beneficiary to some international trade and investment agreements.

The World Trade Organization (WTO) trade policies launched in past decades sought to enhance an inward investment environment. The African Growth and Opportunities Act (AGOA) too attempted to improve the level of FDI in Lesotho. Under the current phase of AGOA, Lesotho and other beneficiaries can export to the European Union (EU) and the United States duty free. This has complemented 
the Cotonou Agreement under which the EU offers duty-free access to most products made in Lesotho. In addition to these factors, through privatisation of state-owned enterprises, the country has offered another incentive for FDI, since privatisation signalled the government's commitment to economic reform.

Though Lesotho is currently obtaining significant FDI from trade privileges, the likelihood is that most of this FDI will be questionable once such privileges expire. For instance, the multi-fibre agreement which put into place export quotas ended in 2004. According to the Economist Intelligence Unit (2006), during 2005 employment in clothing and textile sub-sector fell by over 20 per cent and the remaining producers were reported to be struggling. To improve the situation, the Lesotho government introduced new incentives for investors including zero company tax on exports outside the Southern African
Customs Union area. Also, through the Lesotho National Development Corporation (LNDC), an investment motivated campaign was launched. The remaining challenge for Lesotho therefore is to improve the base for existing foreign operations as well as to further raise its attractiveness to FDI.

This paper extends the existing empirical literature on the determinants of FDI in Lesotho by employing a regression analysis that takes into consideration the extent of export orientation in the country, the macroeconomic stability and political stability, and how these factors affect FDI. The remainder of the paper is organized as follows: section two provides a review of literature, section 3 discusses FDI trends, determinants and constraints in Lesotho, section 4 discusses methodology and data analysis and section 5 presents the findings of the study. Section 6 concludes the study.

Table 1

Lesotho's economic indicators

\begin{tabular}{|l|c|c|c|c|c|}
\hline & $\mathbf{2 0 0 1}$ & $\mathbf{2 0 0 2}$ & $\mathbf{2 0 0 3}$ & $\mathbf{2 0 0 4}$ & $\mathbf{2 0 0 5}$ \\
\hline GDP (M billion) & 6.5 & 7.6 & 8.3 & 8.6 & 9.5 \\
\hline Real GDP growth (per cent) & 3.2 & 3.8 & 3.3 & 3.0 & 1.2 \\
\hline CPI (average per cent) & -9.7 & 33.9 & 6.7 & 5.1 & 3.5 \\
\hline Population (million) & 1.8 & 1.8 & 1.8 & 1.8 & 1.8 \\
\hline Exports (US\$ million) & 278.6 & 357.3 & 475.0 & 707.3 & 740.2 \\
\hline Imports (US\$ million) & 678.6 & 762.7 & 994.4 & 1302.0 & 1358.3 \\
\hline $\begin{array}{l}\text { Current account balance } \\
\text { (US\$ million) }\end{array}$ & -95.1 & -126.7 & -134.7 & -76.0 & -61.0 \\
\hline $\begin{array}{l}\text { Nominal exchange rate } \\
\text { (average) M:US\$ }\end{array}$ & 8.6 & 10.5 & 7.6 & 6.5 & 6.4 \\
\hline Per capita consumption (M) & & & & & \\
\hline
\end{tabular}

Source: Economist Intelligence Unit, 2006

\section{Literature review}

The related literature classifies FDI types as either market-seeking or export-oriented. Market-seeking FDI involves the production of goods in the host country and their sale in the local market. The most important factor to attract this type of FDI is the size and growth of the host country. In export-oriented FDI, goods are produced in the host country but sold abroad. The empirical evidence on FDI has been 
developed around the lines that FDI is by and large determined by macroeconomic factors and political factors. Most empirical studies analyse factors such as market size, openness of the economy and/or export orientation, domestic labour market conditions, exchange rate stability, FDI regulatory framework and political instability as having a significant impact on FDI.

In FDI literature, market size is seen as an enabling factor for economies of scale exploitation. As Chunlai (1997) maintains, a large market is necessary for efficient utilisation of resources and exploitation of economies of scale. Jenkins and Thomas (2002) identify the most important motivation for investment in Southern Africa as being the size of the local market. The other factor in attracting FDI inflows concerns the openness of the economy or export orientation. Tsikata, Asante and Giyasi (2000) maintain that an export-oriented economy is assumed to have a positive influence of FDI inflows since it opens the vents for future exportation of excess output.

In efforts to attract FDI, policy makers are encouraged to improve internal political climate and regulatory frameworks. These measures, according to Asiedu (2003), could have a positive impact on investor sentiment and hence FDI. The determination of real exchange rates too is of crucial importance to an understanding of the links between domestic and foreign currencies (Juselius, 1995). A fairly weak exchange rate is believed to encourage exports even though care must be taken to avoid excessive depreciation of the domestic currency as this could trigger foreign price inflation.

FDI literature also puts forward labour market conditions as a significant factor in investment decisions by foreign affiliates. Investors can be attracted or deterred by the cost and productivity of labour. As OECD (2000) indicates, one of China's important advantages in attracting FDI is its competitive production factors: high quality labourers whose average salaries remain at a relatively low level.

\section{3 \\ FDI in Lesotho: trends, determinants and constraints}

\subsection{Trends}

During the late 1960s, the Lesotho National Development Corporation was established with the view of initiating, promoting and facilitating investment particularly to aid the development of manufacturing and processing industries, mining and commerce. The period after 1970 saw relatively stable FDI inflows though at low levels. The annual average FDI inflows hardly exceeded US\$ 4 million. FDI inflows in Lesotho continued on that modest growth path until after the IMF stabilisation programme of 1988. For the first time in history, Lesotho's FDI inflows then rose to a peak of US\$21 million, which is far beyond what the country used to record (UNCTAD, 2003). In the subsequent years, annual inflows were maintained at levels that were higher than the pre-1988 level, although they did not again reach the 1998 peak until 1994, when a surge of investment brought annual FDI inflows to US $\$ 43$ million. This is partly explained by privatisation of some of the state enterprises.

During the remainder of the 1990s, FDI inflows maintained similarly high levels, indicating a respectable performance in terms of FDI size and growth. However, the September 1998 political riots redirected and destabilised the flow of FDI, partly as a result of looting and other destruction of physical property. This was reflected in a 39 per cent fall in FDI in 1999 followed by a 27 per cent fall in 2000 . To Lesotho's relief, the initiation of the Africa Growth and Opportunity Act (AGOA) in 2000 meant positive prospects for Lesotho's FDI stance, and a growth rate of 25 per cent was reported in the manufacturing sub-sector alone that year. 
Table 2

FDI inflows into Lesotho

\begin{tabular}{|l|c|c|c|}
\hline Phase (years) & $\begin{array}{c}\text { FDI inflow } \\
\text { (US \$ million) }\end{array}$ & $\begin{array}{c}\text { Annual average } \\
\text { (US\$ million) }\end{array}$ & $\begin{array}{c}\text { Average rate of increase } \\
\text { (per cent) }\end{array}$ \\
\hline $1970-1980$ & 32 & 3 & 17 \\
$1981-1989$ & 59 & 7 & 35 \\
$1990-2001$ & 1555 & 130 & 60 \\
\hline
\end{tabular}

Compiled from EIU data

\subsection{Determinants and constraints}

$\mathrm{n}$ the study conducted by Basu and Sinivasan (2002) on FDI in Southern Africa, FDI in Lesotho is found to be driven by "specific" location advantages, which relate to the opportunity to serve the South African market. This is because in the late 1980s and early 1990s, when South Africa was facing economic sanctions, investors wishing to cater to its large market, located their enterprises in Lesotho.

The country's location advantage is complemented by other factors, including, particularly, a strong investment programme that offers a wide range of investment incentives. Some of these incentives are in the form of relief in start-up and research costs, in which investors are offered amortisation. This helps with expenditure in starting up a business. The government has also introduced a new tax incentive, namely zero company tax on exports outside the Southern African Customs area (Economist Intelligence Unit, 2006).

The second complementing factor in favour of Lesotho's FDI is attributed to its relatively cheap labour force. Drawing an example from the manufacturing sector, Riley and Benvenisti (1998) indicate that some garment manufacturers were initially attracted by Lesotho's low unit labour costs. Table 3 below shows the differences in unit labour costs between Lesotho and South Africa.

Table 3

Unit labour costs in manufacturing (Index $2000=100$ )

\begin{tabular}{|l|c|c|}
\hline Year & Lesotho's labour cost & South Africa's labour cost \\
\hline 1994 & 59 & 76 \\
\hline 1998 & 86 & 92 \\
\hline 1999 & 94 & 98 \\
\hline 2000 & 100 & 100 \\
\hline
\end{tabular}

Compiled from Lesotho (2000) and South African Reserve Bank (2006)

The table indicates that in 1994, for example, the average labour cost in Lesotho was 41 per cent lower than in 2000. During the same period, South Africa's unit labour cost was only 24 per cent lower. The years 1998 and 1999 too show that unit labour costs in South Africa are higher than in Lesotho.

Even though Lesotho has succeeded in improving its investment climate, there are certain constraints to investment that still prevail in the country. Some of these constraints are identified in the Enterprise Survey conducted by the World Bank Group in 2003. The survey covered about 75 firms from Lesotho. Table 4 summarises the survey results, which also provide an investment climate snapshot for the sub-Saharan Africa region as well. About 54 per cent of the firms 
interviewed stated that access to and cost of financing is a major constraint. This is followed by crime, tax administration and corruption. Regionally, the main obstacles are access to financing, macroeconomic instability, electricity availability and corruption. The results indicate that the constraints to FDI in Lesotho compare better to those at the regional level.

\section{Table 4}

Constraints on FDI in Lesotho: Percentage of firms identifying a problem as a major obstacle

\begin{tabular}{|l|c|c|}
\hline & Lesotho & Sub-Saharan Africa \\
\hline Access to financing & 54 & 61 \\
\hline Crime, theft and disorder & 46 & 27 \\
\hline Tax administration & 43 & 47 \\
\hline Tax rates & 42 & 45 \\
\hline Macroeconomic instability & 37 & 40 \\
\hline Corruption & 35 & 42 \\
\hline Electricity availability & 35 & 34 \\
\hline Economic policy uncertainty & 31 & 30 \\
\hline Workers' skills and education & 29 & 24 \\
\hline Access to land & 28 & \\
\hline
\end{tabular}

\section{4}

\section{Methodology and description} of data

\subsection{Method of study}

The econometric method employed is the Johansen multivariate cointegration approach, which allows for modelling of the long-term relationship of non-stationary variables. This suggests that cointegration techniques are basically used to establish whether a longterm equilibrium or stationary relationship exists between non-stationary variables in a system of equations or in a single equation. In such relationships, it can be deduced that the dependent variable may depend not only on the level of the explanatory variables but also on the extent of disequilibrium between the levels of the explanatory variables and the dependent variable. Once a set of variables proves to be cointegrated, the error correction model (ECM) can be constructed. The appeal of the ECM is that it combines the interaction between short-term and long-term impacts in a given relationship (Gani, 1999).

The Johansen approach begins by defining a general polynomial distributed lag model of a vector of variable $X$ as an unrestricted vector auto-regression (VAR) in the level of $\mathrm{X}$ variables such that:

$$
\mathrm{X}_{t}=\Pi_{1} \mathrm{X}_{t-1}+\ldots+\Pi_{k} \mathrm{X}_{t-k}+\varepsilon_{1}(\mathrm{t}=1, \ldots . \mathrm{T})
$$

where $\mathrm{X}$ is a vector of $\mathrm{p}$ variables, all of which are non-stationary and $\Pi_{1}, \ldots \Pi_{k}$ are pxp matrices of unknown parameters $\alpha$ and $\beta$. These parameters are estimated on the basis of $\mathrm{T}$ observations from a VAR process. The minimum lag of the system is chosen at which the residuals are white noise. Since economic time series are generally non-stationary processes, the VAR system above is usually expressed in first difference form. However, unless the difference operator is also applied to the error process and explicitly taken account of, differencing implies loss of information (Johansen \& Juselius 1990). The 
above VAR system is therefore re-parameterised in as error correction form as:

$\Delta \mathrm{X}_{t}=\Gamma \Delta \mathrm{X}_{t-1}+\ldots+\Gamma_{k-1} \Delta \mathrm{X}_{t-k+1}+\Pi \mathrm{X}_{t-k}+\varepsilon_{1}$

where

$\Gamma_{\mathrm{i}}=-\left(\mathrm{I}-\Pi_{1}-\ldots . . \Pi_{\mathrm{i}}\right) \quad(\mathrm{i}=1$

$\Pi=-\left(\mathrm{I}-\Pi_{1}-\ldots \Pi_{\mathrm{k}}\right) \quad(\mathrm{i}=1$

The columns of the matrix $\beta$ are the $r$ distinct cointegrating vectors and $\alpha$ is called the adjustment matrix. It represents the matrix of weights with which each cointegrating vector enters each equation of the VAR system.

\subsection{Description of data and variables}

The study uses time series data for the period 19732004. The dependent variable is FDI inflow. The independent variables are provided below:

\section{Macroeconomic stability (Real exchange rates)}

The study includes real exchange rates as a proxy for macroeconomic stability. Since most of Lesotho's FDI is export-oriented, a depreciation of the local currency is assumed to attract FDI.

\section{Export orientation}

This is measured by the ratio of exports to GDP. For smaller, developing economies, outward-oriented rather than inward-oriented FDI is more predominant. There is a perceived positive relationship between export orientation and FDI.

\section{Market size}

Since much of Lesotho's FDI does not target Lesotho per se, but South Africa, we include
South Africa's GDP growth as a measure of market size.

\section{Political instability}

This is expected to have a deterrent effect on FDI. The study uses a dummy for the following aspects of political instability: Coups, forced changes of government and violent demonstrations. We assign value 1 for successive periods of instability and zero otherwise.

The functional relationship to be estimated is therefore presented as:

$\mathrm{FDI}=\mathrm{f}$ (EXRATE, GDPSA, EXPGDP, POLINS)

where

EXRATE = real exchange rate $($ a proxy for macroeconomic stability)

GDPSA = South Africa's real GDP growth (a proxy for the market)

EXPGDP $=$ ratio of exports to GDP (measure of export orientation)

POLINS = dummy for unstable years (measure of political instability)

\subsection{Estimation and presentation of the results}

To avoid spurious results due to the nonstationary characteristic of time series data, unit root tests were done on the data. This was followed by a cointegration test, which, as explained above, is a prerequisite for error correction modelling. The empirical results are presented in table 5 .

Table 5

FDI regression results

\begin{tabular}{|l|c|c|c|c|}
\hline Variable & Coefficient & Standard error & t-Statistic & Probability \\
\hline GDPSA & 5.356805 & 1.898659 & 2.821363 & 0.0094 \\
\hline RXRATE & 2.137914 & 0.681589 & 3.136660 & 0.0045 \\
\hline EXPTORIE & 726.4233 & 463.5742 & 1.567005 & 0.1302 \\
\hline POLINS & -31.17992 & 10.18896 & -3.060167 & 0.0054 \\
\hline C & 21.67938 & 6.598199 & 3.285652 & 0.0031 \\
\hline
\end{tabular}


All the variables from the regression have the expected signs. The indication is that the South African market size and export orientation promote Lesotho's FDI. Furthermore, the real exchange rate seems to be in favour of the country's FDI since the results exhibit a positive coefficient. A significant political instability dummy is a clear indication that civil unrest to some extent has a negative effect on FDI.

\section{5}

\section{Conclusion}

Drawing on a time series analysis and relevant literature, the study finds on the one hand that South African market size, macroeconomic stability and export orientation have a positive impact on FDI in Lesotho. and on the other that political instability impacts negatively on FDI. While investment incentive policies have created a recent surge in foreign investments, Lesotho still faces serious challenges, as it is largely dependent on time-bound privileges that are mostly biased towards the clothing and garment sub-sector. Also, it cannot be denied that part of past foreign investment in Lesotho was mainly driven by the global sanctions on South Africa during the apartheid era. Given the current post-apartheid era in South Africa, Lesotho faces yet another possible challenge, that of investor-drain into South Africa due to the higher level of development and better business prospects in that country. In the short and medium term, the Lesotho government could improve human capital development and infrastructural development and implement a diversified investment promotion programme.

In the longer term, the government could consider nurturing a political and bureaucratic environment that will encourage foreign investment by putting an end to corruption and post-election conflicts. The government should also seek to implement political risk insurance to provide coverage for private investments.

\section{References}

1 ASIEDU, E. (2003) Foreign Direct Investment to Africa: The Role of Government Policy, Governance and Political Instability, Department of Economics, University of Kansas: Kansas.

2 BASU, A. \& SRINIVASAN, K. (2002) "Foreign direct investment in Africa: Some case studies", IMF Working Paper WP/02/61, International Monetary Fund: Washington.

3 CHUNLAI, C. (1997) "The location determinants of foreign direct investment in developing countries", CERC, University of Adelaide: Adelaide.

4 ECONOMIST INTELLIGENCE UNIT (2006)

"Lesotho country report" (July 2006), http://www. eiu.org_(Accessed 20 September 2006).

5 GANI, A. (1999) "Foreign direct investment in Fiji”, Pacific Economic Bulletin, 14(1): 87-92.

6 JENKINS, C. \& THOMAS, L. (2002)

"Foreign direct investment in Southern Africa: Determinants, characteristics and implications for economic growth and poverty alleviation", $C S A E$ CREFSA, London School of Economics: London.

7 JOHANSEN, S \& JUSELIUS, K. (1990)

"Maximum likelihood estimation and inference on cointegration - With applications to the demand for money", Oxford Bulletin of Economics and Statistics, 52(2): 169-210.

8 JUSELIUS, K. (1995) "Do purchasing power parity and uncovered interest rate parity hold in the long run? An example of likelihood inference in a multivariate time series model", Journal of Econometrics, 69(1): 211-240.

9 LESOTHO. (2000) Lesotho Government Gazette No 91, Lesotho Government Publishers: Maseru.

10 LNDC INVESTORS GUIDE (2006) "Investors guide", www.lndc.org.ls/ investors.htm (Accessed 04 August 2006).

11 OECD (2000) "Main determinants of foreign direct investment on China's economy", $O E C D$ Working paper number 2000/4, OECD: Tokyo.

12 RILEY, T. \& BENVENISTI, T. (1998) “A diagnostic review of Lesotho's investment environment", Foreign Investment Advisory Service, The World Bank: Washington.

13 SOUTH AFRICAN RESERVE BANK (2006). South African Reserve Bank Quarterly Bulletins, http://www.reservebank.co.za (Accessed 31 October 2006). 
14 TSIKATA, G.K., ASANTE, Y. \& GYASI, (2000) "Determinants of foreign direct investment in Ghana", Overseas Development Institute, University of Ghana: Legon.

15 UNCTAD (1995) World Investment Report, UNCTAD: Geneva.

16 UNCTAD (2003) Lesotho Investment Policy Review, UNCTAD: Geneva.
17 WIDSTRAND, C. \& AMIN, S. (1975) Multinational Firms in Africa, Uppsala Offset Center AB: Sweden.

18 WORLD BANK (2003) Enterprise Surveys, The World Bank Group, Washington http://www. enterprisesurveys.org (Accessed 17 October 2006). 